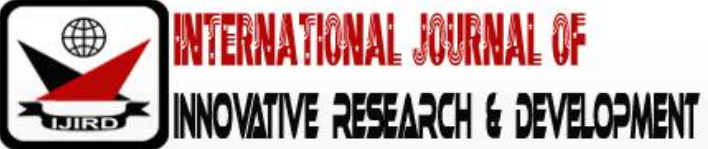

ISSN 2278 - 0211 (Online)

\section{Women in Development: The Historical Trends of Changing Roles of Women in African Society}

\author{
Akinwale, Fehintola Tunbosun \\ Academic Advisor, Department of History, University of Ibadan, Nigeria
}

\begin{abstract}
:
The role of women in the advancement of humanity is dated back to the time immemorial. The survival of the family which is seen as a nucleus of the society depends to a large extent on the woman. This is because the woman performs the primary roles a mother, wife, counselor, a home manager, care-giver to mention but few. In addition, African women play significant roles in educating and teaching their children in social, ethical, and moral values which are part of the cultural standards for evaluating a proper and ideal societal behaviour. This is why Manuh argues that '...the functions of women in the political and socio-economic development of modern Africa cannot be overemphasized.' ${ }^{\prime}$ This is to say that their positive contributions to their household, food production system and national economies which are increasingly acknowledged within Africa and by international community. This is as a result of their concerted efforts in organising and articulating their concern as well as making their voices to be heard at every available opportunity. Beyond this, the continued participation of women in all fields of human endeavours has shifted them from the slideshow to the centre stage of development. This is evident in their participatory roles both in the rural and national economies, politics, academia, sports, entertainment, etc.

This paper therefore, highlights the indispensable roles of women in African society right from the pre-colonial through post-colonialperiod. The paper adopts economic, politics, social and so on as a means of interrogating their activities and contributions to the growth and development of the contemporary society.
\end{abstract}

Keywords: Changing roles, women in development, African society

\section{Introduction}

The contributions of women towards the social, economic, political and educational development of African societies cannot be gainsaid. Each gender [male and female] had its traditional role in the development of the society. In other words, the position of women was complimentary to that of men. Each role regardless of who performed it was considered important because of their contributions to the fundamental goal of community survival. That is to say, indigenous people in Africa performed varying roles to maintain the efficient functioning of their society, prior to colonialism.

In spite of the complimentary role woman played to men, the dynamism that prevailed was that there existed the patriarchy system where men were still seen as the head of the family and leader of the society. This therefore shows that traditional African was not based on gender inequality but a compliment of gender, because each gender had a role to play in contributing to the societal development. In spite of this, so many women have taken the bull by the horn to enhance the development and continuous existence of their society from time immemorial till date.

\section{The Roles of Women in Pre-Colonial African Society}

A woman derives her societal status from two major roles - the role of a mother and a wife. As a mother, the woman is the primary custodian of the cherished value of the society of preserving the activities of procreation. The woman is the channel through which children come into the world and procreation of human race is being sustained. Thus, a woman has as many children as possible, while she equally enjoys her higher social status and a sense of fulfillment if she is able to be delivered of male children. ${ }^{i}$ Evaluating the status and standing position of women in traditional African society, Leith reiterates that women were treated with unparalleled respect because they were seen to be closer to God than men ever had the potential of being. This is because women had the ability to create due to their ability to give birth. As a creator of life, they are charged with sacred responsibility of caring for the next generation and because of this, they can be regarded as the originator of the idea that is now known as sustainable human development.ii

Women's role in traditional African society is sine qua non to societal development. The impacts of women were felt in every aspect of life in the society. They had extensive knowledge of the natural environment; they are gatherers. They complement men's effort in tiling the soil so as to provide and supply both crop and food production for survival. To a reasonable extent, their communities depended on them to provide nourishment or they would face starvation. Traditional women held vital knowledge of herbs and medicines that also ensured the survival of their communities. 
What women do and are expected to do is different in nature as regards economy, politics, religion, ideology, culture etc. but there is a common task which women despite the race, colour, or any other variations throughout the world are expected to perform. These roles include, cooking, sweeping, general cleaning of the house, rearing of children, care for the sick, care for elders and so on. These are the basic responsibilities of women. In most part of African societies, cooking has always been seen as one of the traditional roles of the woman hence in girl-child's training/upbringing, the act of cooking is incorporated into her training while the boy-child is kept away from the kitchen. In the case of men, whenever they feel like lending a helping hand to share in the work undertaken by women, their tasks do not involve domestic work. Once men return from work, they retire to leisure pursuit like eating, gaming, drinking and so on. Often time, men's domestic tasks, where they do any, tend to be communal- house building or thatching. ${ }^{\text {iiiFurthermore, }}$ production of a significant proportion of the household economic resources, whether this is production of food crops, care of herbs, or work in storage and processing of crops; both for food and seed or whether it is production of cash crops and/or craft products for sale, it is often said that rural women must bear a double burden-long hours in the farms or in the craft production and then equally long hours in child-care, food preparation, cooking, washing and cleaning.

A major feature of traditional African society is the patriarchal structure. It is a system of social stratification and differentiation on the basis of sex which provides material advantage to males while placing severe constraint on the roles and activities of females. There are clearly defined sex rules, while various taboos ensure conformity with specified gender roles. Among the Yoruba of Southwestern Nigeria, women kneel in front of their husband as a visible sign of wives' subordinate position to their husbands. Brain who studied the Lugar society of Tanzania (a matrilineal society), found that even though the Luguru women were politically outspoken, and had economic autonomy, there were some cultural factors that reinforced the male supremacyiv that provides better opportunity to them than the women folk. Farming was the major occupation of the Pre-Colonial African society with the women taking prominent roles. Within the traditional African structure, the basic division of labour was largely based on age, and sex. Men naturally gained access to land as lineage member, while most of the time, women gained access to land as wives, daughters, and such access is often limited.v

Similarly, women's roles in the development of the home as mothers and wives, and the state as policy makers, monarchs and even warriors have been quite legendary. African women featured prominently in the socio-economic and political development in Pre-Colonial Africa. They played significant economic roles within the societies as traders and entrepreneurs. This simply means that they were able to accumulate wealth and establish a notable degree of autonomy for themselves. Since wealth and economic independence guaranteed increased socio- political status, consequence upon this, women seized the opportunity to promote their status.

In Yorubaland for instance, the tradition permits a man to marry as many wives as possible. The commonest vocation then was farming. Wives and children help on the farm as a constant and certain means of labour while their pains and gains are shared by the family members. During this period, trade by barter was the only recognised means of exchange of goods and services. As the society advances, exchange of goods and services became replaced with cowries, precious metals, and ornaments to mention but few. Material possession by women thus, gave them prominence in the society. Therefore, as the society continues to evolve, various means of trading activities emerged and women were seen as being prominent in their enterprise. Notable women who had gained political recognition in various societies as a result of their economic success include Madam Efunroye Tinubu of Egbaland and Madam Efunsetan Aniwura of Ibadanland both in Western part of Nigeria to mention but a few. These were significant successful Yoruba entrepreneurs that have gained political influence through commerce. Madam Tinubu played a vital role in resisting the European invasion of Egbaland through the purchasing and supplying Egba Warriors weapons of war to fight against the Europeans. Consequent upon her affluence, political dexterity and her notable contributions towards her community, she was honoured with the chieftaincy title of Iyalode of Abeokuta in 1864.

In addition, was the production of a significant proportion of the household economic resources. This includes the production of food crops, care of herds, or work in storage and processing of crops; both for food and seed or whether it is production of cash crops and /or craft production for sale, it is often said that rural women must bear a double burden, that is, long hours in the farms or in the craft production and then equally long hours in child-care, food preparation, cooking, washing and cleaning.vi

Interestingly, the kinship structure, residence pattern and marriage practices and attitudes across the different ethnic groups, put men in a vantage position above their female counterparts. Thus, like most other patriarchal societies of the world, a Nigerian woman is socialized in a culture of female subordination,viithe cultural ideology that devalues a woman. The etymology behind the idea is that a woman is less-prestigious as well as less-privileged and she is therefore, considered inferior to men in all degrees. They [men] see some realms where the topmost power of the society resides as forbidden to women, let alone participating or in contact with such. A Yoruba man like any other man in Africa for instance, in traditional polygamous arrangement, was highly placed above women, for he controls the procreation ability of his wives as well as their labour. Among the Tiv of Nigeria, for instance, the overall lower status of women compared to men is summed up in what Ityavyar identified as a common saying among the Tivs, 'Kwase Hemen Tyayga' (a woman does not lead a battle). viii Due to these reasons leadership is generally assigned to the men, while girls were treated as parcels to be exchanged in marriage hence, more often girls were forced into marriage without being able to make a choice.

Onaiwu opines that the pre-colonial African women's access to power depend largely on the political structure that is on ground, that is, the political system, class kingship relations, marriage links, economic structures and the capacity, and effectiveness of women's organization. For instance, the case where the position of the 'Queen's Mother' exists, they wielded enormous political power. A typical example is the Asante society. The Asantehene headed the confederation of the Asante states. In order to crown the Asantehene, a candidate for the stool is nominated by the Queen's 
Mother (Ohema). Hence, both of them [Ohema and the Asantehene] have jurisdiction over males and females in recognition of important status, her stool was also considered the most senior in the pre-colonial Asante Union. In Kanem Borno, the Magira was considered to be very powerful politically to the extent that whatever policy or decision made by the Mai, without her consent such decision is rendered invalid. Record has it that in the pre-dynastic Benin, among the thirty-one Ogiso chiefs that ruled, three were women. ${ }^{\text {ix }}$ Queen Idia of Benin kingdom played the prominent role of Queen's Mother with outstanding records. In the pre-Jihad Hausa states, women wielded notable political power. Examples are Queen Amina and Queen Daura. With the success of Islamic Revolution, these women lost their high esteemed political and economic positions.

Females relevance and contribution is of immerse value to the evolution and the development of Africa. Despite all the roles played by women in the pre-colonial African societies, they were yet unable to explore their full potentials as they occupied a minute percentage of strategic position in the societal endeavour. To a large extent woman lack autonomy in traditional African societies, this resulted from the fact that the position occupied by men that are mostly highly elevated positions like Oba, Chief, Obi, and so on are of greater percentage compared to their female counterparts.

\section{African Women in the Colonial Era}

African women status through the structural gender inequalities introduced by the British system of education, commerce, government, and wage employment is quite unappreciated by most female folks. The educational curricula during colonialism were at a disadvantage to the girl-child ${ }^{x}$ and were used by the colonialist to determine certain privileges as regards to women. Colonialism led to the changing roles of women in African society. The 'PULL'xi factor and the opportunities offered by the new cities induced the limited opportunities of the countryside. As a result, the movement to the city results in discontinuity in the role of women in traditional setting.

African women perspectives or involvement in politics during the colonial era, their economic standpoint-the roles played by them/economic interactions with the colonial masters/ improved standard of living, religious involvement -changing of orientations towards accepting the foreign religion as being superior to their traditional religion or belief, the flavour improved social status -by creating class system in the society as a result of their interaction with the colonists, cultural impact of the presence of colonists on African women in terms of dressing, subsuming of African culture-respect of one's husband (kneeling to greet ones husband either early in the morning, speaking with the man without a direct eye contact, that is bowing of the head in the course of talking in some cultures, while the woman kneels as a long as the man sits to eating on the table. Sometime, the woman carries the food on her head while kneeling. Thus, the man eats right from the plate put on her head [Ekiti, in Nigeria]). Even though, the girl-child has not been equally advantaged as the boy-child emanating from the perspectives of the African belief that whatever level of education a girl's attainment in life, she takes all the knowledge and training to her husband's house and therefore, all the investment amounts to colossal waste. The advent of western education at this period enable the girl-child to see herself as a prospective potential thus, increase her self-esteem and planned for better future ahead. This avails her opportunity of having an equal leverage with the boy in terms of economic value to the society as a whole and no longer relegated to the house-keeping or kitchen alone.

It is worthy of note that the advent of Europeans with their colonial economy, which was export oriented, altered the traditional occupation of women. With the emergence of expatriate firms such as United African Company (UAC), and others, local markets which hitherto were dominated by women was gradually disjointed. The introduction of cassava, coinage currency, and the expanded market for palm produce had resulted in many more women especially in Onitsha, Opobo etc. being involved as middle women in the palm oil and palm kernel trade with the Europeans. They in turn purchase imported goods such as mirror, cloth, tobacco, gun powder, spirit, etc. for sales to the villagers. Their contact with the European trader therefore, created a class in the society. It also brought about wage labour. Subsequent to the monetization of the African economy by colonial administrators with the growth of capitalism, the traditional division of labour became modified.xii

Worth mentioning is the fact that African women contributed their own quota to the development of the society during the period under consideration. Margaret Ekpo was one of the prominent leaders during the Aba Riot of 1929 in Nigeria. She was thereafter, elected into the National Executive Council of the National Council of Nigerian Citizen (NCNC) in 1953, a Special Member of the Eastern House of Chiefs in 1956 and Vice President NCNC Women's Wing in Eastern part of Nigeria. Mrs. Funmilayo Ransome Kuti was also an elected member in the Nigerian Western House of Chiefs. xiii It is worthy of note that African Women contributed immensely to African development during the decolonization process of Africa. For instance, in Zimbabwe, women were encouraged to participate in the liberation struggles- they participate in the guerilla war alongside their male counterparts. Women in Kenya enlisted to fight in the Mau-Mau revolts and also took part in the liberation struggle. Their participation was a great challenge to womanhood in African society; hence, women were perceived far from been a passive object but as an agent of change for better society.

\section{The Changing Roles of Women in Postcolonial Era; Post Beijing Conference}

The passion and the drive to promote women's participation to decision making position worldwide gained momentum through a series of conferences such as the Fourth in the series of World Conference on women in Beijing held 4-5 September, 1995 showcasing the reactions of the world to the question of women.xiv The first was held of the conference was held in Mexico (1975), Copenhagen (1980) and the third in Nairobi (1985) respectively. The theme of the conference is 'Equality, Development and Peace'. A total number of 17,000 participants from 189 countries attended the conference. The Conference calls for 30 percent representation of women in National Government. Consequent upon this, in September, 2002, at the United Nations Summit in New York, World Leaders pledged to 'promote gender equality, make audible the voice of women, ensure participation of women in both public and private life, empowerment of women as 
effective way to combat poverty, hunger and disease and stimulate development that is truly sustainable,'xvto recognise the human right and dignity of both men and women as enshrined in the Charter of the United Nations while eliminating all forms of discrimination and violence against women.xviThus, Beijing Declaration and Platform for Action calls for the dedication and commitment of all participation government and international communities to gear actions towards the advancement and empowerment of women in the following significant areas; to create enabling environment to women, security of human right of both women and girl-child, equal participation in every strata of the society and in decision making process, sustenance of economic, social and environmental growth through poverty eradication, attainment of local, regional and international peace through advancement of women, removal of all forms of discriminations against women and girl-child, provision of education and primary health care for both women and girls, and to provide equal access to economic resources such as land, science and technology, credit, vocational training, information, communication and markets to women and girls. xvii In the closing remarks of the programme, the conference calls for government and participating nations to support the United Nations, regional, financial institutions, men, women, Non-governmental Organisations, all sectors of civil societies to cooperate with government in this quest.xvii

In a bid to execute and implement the 30 percent Affirmative Actions, the 1995 Beijing Conference, recommended that women should be allocated positions in the political arena, power and decision making. As part of efforts in fulfilling the declaration in Nigeria, the National Gender Policy, Gender Activists and Civil Society Organizations, such as the National Coalition on Affirmative Action staged enlightenment programmes/campaigns of advocacy, training and research on Affirmative Action to encourage female participation in politics. Resultantly, the proportion of seats held by women in the National Parliament increased from 3.1\% in 2000 to $7.5 \%$ in 2008 . The records have it that after the 2007 elections, data from the National Centre for Women Development showed that there 9 female Senators, 26 female Members in the House of Representatives against 23 Members in 2006. There were 54 female Members in the House of Representative, in the State Assemblies. Female Deputy Governors increased to 6 in 2007.xix 2012 marked a great landmark in the history of Nigeria when a female rose to a highly esteemed position in the Judiciary to become the first female Justice in Nigeria.

\section{The Changing Roles of Women in Cotemporary African Society}

Daily, African women are writing their names in gold. Several monumental achievements were recorded to their credit in all spheres of human endeavour. For instance, women in Africa are increasingly making waves in the political stage. In the word of Gisela Geisler, Africa has long been 'extremely progressive when it comes to women in politics'xxwomen such as Liberian President, Mrs. Ellen Johnson Sirleaf and Mrs. Okonjo Iweala, former Managing Director of the World Bank and one time Nigerian Finance Minister, are usually cited as point of reference in African women in political positions, a sign of gender equality. In addition, President Goodluck Jonathan was the first Nigerian President in history to appoint 13 women out of 41 Ministers as members of his cabinet. The women that set the precedent were; Obiageli Ezekwesili, Vice President of the World Bank for African Region, Prof. Dora Akunyili, former Director General of National Agency for Food and Drug Administration and Control (NAFDAC) of Nigeria and former Nigerian Minister of Information and Communication, and Mrs. Patricia Olubunmi Etteh, the first female Speaker of the House of Representatives and a host of others.

Quota systems adopted by most African countries ensure women's participation in politics and Institutional integration. In Rwanda, women had $48.8 \%$ of Seats in the lower House of Parliament in 2003, while women in Rwandan Upper House are guaranteed 30\% Seats. To this end, Rwandan women lobbied to draft the new Constitution and developed voting guidelines that guaranteed more Seats for female candidates. They were able to push through for the creation of Ministry of Women's Affairs, to enhance policies that are female-friendly. As a result, the government of President Yoweri Museven appointed Dr. Wandira Kazibwe as Vice President thus making her one of the highestrankingwomen in Africa.

Being part of the development after the conference, funding is provided for women in Zimbabwe on special projects so as to assist them into breaking new grounds, that is to identify key positions where they need to be placed in

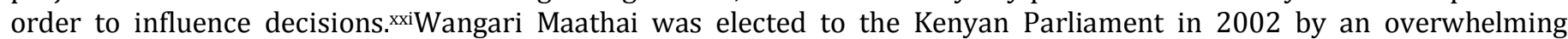
majority. Also, in 2003, African Union took a bold step in promoting gender parity in her top-decision making position. Five men and five women were elected as commissioners. The following year, Ms. Gertrude Mongella was appointed to head the AU's Pan-African parliament. Here, women make up 25\% of the members. In addition, 51 out of 53 membercountries ratified the Convention on the 'Elimination of all Forms of Discrimination Against Women (CEDAW), a body that supports and promotes the human rights of women. Similarly, women began to participate in politics in Tunisia. They play significant roles in campaigns, amendment the electoral lawand elections.For instance, the National Constituent Assembly (NCA) seats are held by women. Political participation of women has increased significantly in most African countries most especially with the assistance of the United Nations, Development Fund for Women (UNIFEM).

South Africa rose to the rank of 4th place in the global ranking of women in Parliament after the April 2012, elections. In South Africa, there is now a culture of zero tolerance for not having women on the table. Women played significant roles in the National liberation struggle and today they are benefitting from the quota system adopted by the ruling party-African National Congress (ANC). As a result of achievements recorded by other women in other countries, the Zambia National Women's Lobby Group accused that its government has ratified a number of international instruments to promote women in politics. Joyce Banda became the first Southern African President and Africa's first female Vice President as a result of the death of the former President BinguwaMutharika on the 5th of April, 2012. She took over the helm of affairs of Malawi on the 7th of April, 2012. 
In the economic scene, as from 1990s, women both at the grass root and at the national level, have found more female participation taking advantage of the new political trend to assert their political status, at the same time press for economic and social advancement. Many of them now belong to certain aid Group and Unionism. These women take active part in agriculture both in the North and South Eastern part of Nigeria. They argue that they have full control in their contribution to agricultural development. Also, Elsie Kanza, a Tanzanian, is currently an assistant advisor to Tanzanian President Jakaya Kikwete. She has been selected by the World Economic Forum as a Young Global leader.

In the religious sphere, women were not left out. They played and still playing the prominent and complementary roles in Pentecostal Movements, African Indigenous Churches and Traditional Shrines. That is why titles such as Mother-in Israel, Lady workers, Reverend Mothers, Lady Evangelists, Iya Olokun, etc. are prominent among African worshippers aims at designating who had founded or co-founded churches or traditional worship centres. ${ }^{\text {xii }}$

In the field of academia, Nigeria as a country has produced many female scholars who had and are still occupying the position of Vice-Chancellors of Universities, University Registrars, Professors, and Doctors in the entire intellectual arena, to mention but few. They are of great repute that had contributed and still contributing immensely to the academia. Worthy of note is Prof. (Mrs.) Bolanle Awe. She was the first Nigerian female in Ph.D. in History in 1964. She became the first woman History Professor in 1978. She headed the Institute of African Studies in 1983 as the first female. Thereafter, she has paddled the canoe of several Government Parastatals and Agencies with monumental achievements to her records. Professor Sylvia Tamale becomes the first female Dean of Makerere University's Faculty of Law in 2004. She has launched a research project on gender, law and sexuality, which she hopes will become a fully-fledged research centre. Postapartheid South Africa, at Johannesburg's University of the Witwatersrand, for instance, women account for $19 \%$ of associate Professors and $17 \%$ of full Professors in recent years.

In the entertainment industry, women have equally played significant roles. Women's roles in sport, music and movie remained a giant feat in the history of Africa. Women have moved from the colonial and patriarchy to become heroines in the movie industry. They have featured as successful promoters, film makers and the like. The industry can boast of Actors and Actresses like Kate Henshaw, Mosun Filani, Bukky Wright, Monalisa Chinda, to mention but few.

African women cannot be left out in the sport. For instance, Super Falcon is a Nigerian National female Soccer Team. The team has at several occasions done Nigerian proud in their several outings even where the male team has failed. Several women from East Africa, Kenya Rugby Football Union have made their feat in sport. Africa has produced female sport gurus like; Chioma Ajunwa, Mary Onyeali, Patt Biodun, Juan Kuffuor, Joyce B. Khumalo, and a host of others.

Despite all the achievements recorded thus far, women are faced with diverse challenges and obstacles. For instance, the International Labour Organisation states that women in most part of African communities earn lower wages compared to their male counterparts. In the same vein, the United Nations says the women do about $66 \%$ of the working hours, yet, they receive only $10 \%$ of the world's income while they own $1 \%$ of propertyxiii as they cannot inherit or own property. This is well described in the experience of women in Swaziland where they are required to seek permission of either the husband or father or both before they could open bank account or go into business or to obtain to passport. The level of domination and control men have over women constitutes major barriers to effective maximization of women's potentials and purpose. To corroborate this view, some societies such as Guinea, Ethiopia and Tanzania encourage boys to engage in income-generating ventures while girls are taught how to involve in domestic activities such as fetching of water, baby-sitting, preparation of food and so on. At delivery, a woman that gives birth to a male child is highly celebrated while the one with a female child is considered as unproductive and may lose her position in the family. As if the above mentioned are not enough, health and well-being challenges are mostly suffered by women. Plagues and other threats to life such as malaria, shortage of food, insecurity, HIV and AIDS, Ebola, Covid-19 pandemic, maternal and child mortalityetc. affect women more than men as the emotional strength of men are stronger than women. According to Olorunbunmi, '...in South Africa, Lesotho, Namibia and Botswana, 50\% of infant deaths is as a result of HIV...at least 3 women contract HIV through a single man while girls of 15 to 19 years of age are 6 times likely to have contracted it compared to boys of same age range...'xxivAlso, the plights of women have not been improved especially in the area of domestic violence, abuse and rape. Study shows that the rate of both girl-child and women abuse and rape is on the increase on daily basis in Nigeria. The victims are not only raped by their abductors but end up killing them or let them go at the verge of giving up the ghost. A good example is Vera Uwalia Omozuwa, a Biochemistry student of University of Benin, Edo State, Nigeria who was raped and sustained a high degree of injuries on 27th May, 2020 and died a few days later. Same was Barakat Bello, 18 years, a student of Federal College of Animal Health and Production Technology, Moore Plantation, Apata, Ibadan, Oyo State, raped and killed few days after Uwa's incidence on 1st of June, 2020. Report has it that another undergraduate, Grace Oshiagwu, a student of the Polytechnic, Oke-Ogun, Saki, Oyo State was raped in her room and killed at her residence, Idi-Ori, Area off Shasha Expressway, Akinyele L.G. A., Ibadan on 13th June, 2020 not quite a distant time from the former and a host of others. Therefore, between January and May, 2020, the Inspector General of Police, Mohammed Adamu reports that Nigeria records 717 rape cases in the country. In his words, 'six hundred and thirty-one cases investigated and charged to court while fifty-two cases are under interrogation.'xxvIn addition, reparation and relief for victim and survivor of violence as well as their plights have not been duly attended to. Study shows that $90 \%$ of war casualties, social vulnerability, and conflict are children and women. For instance, widowhood in Eastern part of Nigeria can be described as a daylight nightmare. When a man dies in Igboland (Eastern Nigeria), the experience is most times horrific. The widow is subjected to hardship; she is compel to drink the water used in bathing the dead body, sleep on the bared floor for a number of days before the internment so that she may die if she is responsible. ${ }^{x x v i B y}$ implication, her health status may be jeopardized. If she survives the traumatic sessions, all the properties may be seized from her most especially if she doesn't have a male child for the late husband. 


\section{Conclusion}

Although women are faced with diverse societal challenges that ranges from gender inequality in politics, academics, socio-economic, even at the home front, changes in the roles of women in African society as witnessed in the past and still witnessing in the contemporary, is a giant trend which denote a revolution towards a great Africa as the hand writing is bold on the wall. In the midst of all odds, African women are determined to see that their dreams come to reality as they continue to strive positively to impact their generation even the generation unborn. Therefore, the society must be prepared to

witness more of these evolving trends in the contemporary world and years to come.

\section{References}

i. Cornwell, A. (2005). Introduction: Perspectives on Gender in Africa. London: Indiana University Press.

ii. Ayegboyin \& Ishola. (1999). African Indigenous Churches. Lagos: Greater Heights Publications.

iii. Dehinde, T. (2005). Women in Development: A Global Perspective. In M. Faseke (Ed.). Nigerian Women Professionals: A Historic Analysis. Lagos: Tidings Publishers.

iv. Beddoe, D.(1983). Discovering Women's History: A Practical Manual. London: Pandora Press.

v. Brain, J. L.(1997). Less than Second-Class: Women in Rural Settlement in Tanzania. In M.J. Hafkin and E. C. Bay (Eds.) African Women in Changing Perspectives. Stanford: Standard University Press.

vi. Effah, S.A. Women in the Development of Nigeria since Pre colonialtimeswww.onlinenigeria.org retrieved $10 / 7 / 2012$

vii. Geisler, G. G. (2004). Women and the Remarking of Politics in Southern Africa: negotiating autonomy, Incorporation and Representation, Nordic African Institute

viii. Ityavyar, D.A. (1992). The Changing Socio-Economic Roles of Tiv Women. Jos: University Press Ltd.

ix. Ross, L.(1967). African Woman. New York: Macmillan Publishers Ltd.

x. Brydon, L.\& Sylvia Chant, S.(1989). Women in the Third World, Gender Issues in Rural and Urban Areas. England: Edward Elgar Publishing Ltd.

xi. Mabogunle, A.L. 1969. Urbanization and Social Change. London: University of London Press, 1969

xii. Mepaiyeda, S. M. (2015). Women in Christian Religion. In S. A. Ajayi \& K.Ayantayo (Eds.). Women in Development: Essay in Memory of Prof. Dorcas Olubanke Akintunde. Ibadan: John Archers Publishers Ltd.

xiii. Olabisi I. Aina. (1998). Women Culture and Society. In S. Amadu\& A. Odebiyi (Eds.), Nigerian Women insociety and Development. Ibadan: Dokun Publishing House.

xiv. Olorunbunmi, B. (2015). Beijing 1995: Its Challenges to Women and Development in Africa. In S. A. Ajayi \& K.Ayantayo (Eds.). Women in Development: Essay in Memory of Prof. Dorcas Olubanke Akintunde. Ibadan: John Archers Publishers Ltd.

xv. Onaiwu 0. (2005). Women, State and Society in Pre-Colonial Africa. Lagos Historical Review. Vol.5

xvi. Uchem Rose. (2003). Overcoming Women's Subordination in The Igbo African Culture and in the Catholic Church, in Annual Journal for Women International Vol. 1 No1

xvii. Oral interview with Mrs. Oramalu. An indigene of Nibo in Anambra State, Nigeria. Age, 63. 09-03-2020.

iOlabisi I. Aina. (1998). Women Culture and Society in AmaduSesay\&AdetanwaOdebiyi (Eds), Nigerian Women in Society and Development. Ibadan: Dokun Publishing House. 6

${ }^{i i}$ Leith Ross. 1967. African Woman. New York: Macmillan Publishers Ltd. 34

iii Lynne Brydon\& Sylvia Chant. 1998. Women in the Third World, Gender Issues in Rural and Urban Areas. England: Edward Elgar Publishing Ltd. 59-60

iv James L. Brain. 1997. Less than Second-Class: Women in Rural Settlement in Tanzania. In M.J.Hafkin\&Edua C. Bay (eds) African Women in Changing Perspectives. Stanford: Standard University Press, 1997. 265-282

volabisi I. Aina. 1998. Women Culture and Society' in AmaduSesay and AdetanwaOdebiyi (eds), Nigerian Women in Society and Development. Ibadan: Dokun Publishing House. 8

vi LynneBrydon\& Sylvia Chant. 1989. Women in the Third World, Gender Issues in Rural and Urban Areas. England : Edward Elgar Publishing Ltd. 59-60

viiolabisi, I. Aina.1998. Women Culture and Society. In AmaduSesay and AdetanwaOdebiyi (eds), Nigerian Women in Society and Development. Ibadan: Dokun Publishing House. 6-7

viii Ityavyar, D.A. 1992. The Changing Socio-Economic Roles of Tiv Women. Jos: University Press Ltd. 35

ix OnaiwuOgbomo. 2005. Women, State and Society in Pre-Colonial Africa. Lagos Historical Review. Vol.5. 60-66

xUchem Rose. 2003. Overcoming Women's Subordination. In The Igbo African Culture and in the CatholicChurch in Annual Journal For Women International Vol. 1 No1.

xiMabogunle, A.L. 1969. Urbanization and Social Change. London: University of London Press.

xii Aina, O. T. 1998. Women Culture and Society' in AmaduSesay and AdetanwaOdebiyi (eds), Nigerian Women in Society and Development. Ibadan: Dokun Publishing House. 16

xiiiAtoe S.A. Effah, 'Women In The Development of Nigeria Since Pre Colonial Times'www.onlinenigeria.org retrieved 10/7/2012

xiv Aina,0. T. 1998.'Women Culture and Society' in AmaduSesay\&Adetanwa, O. (eds), Nigerian Women in Society and Development . Ibadan: Dokun

Publishing House. 19

xv Andrea, Cornwell. 2005. Introduction: Perspectives on Gender in Africa. In Gender in Africa, Andrea Cornwell (ed). London: Indiana University. 1

xvi United Nations Report of the Fourth World Conference on Women, Beijing, 4-5 September, 1995, United Nations Publication. 1996. 2

xvii United Nations Report of the Fourth World Conference on Women, Beijing, 4-5 September, 1995, United Nations Publication. 1996. 2

xviii The Beijing Declaration and the Platform for Action: Fourth World Conference on Women, Beijing China, 4-5 September, 1995, Department of Public Information, United Nations, 1996. 74 
xix Deirdre, Beddoe. 1983. Discovering Women's History: A Practical Manual. London: Pandora Press. 5-39

xx Gisela G. Geisler. 2004. Women and the Remarking of Politics in Southern Africa: Negotiating Autonomy, Incorporation and Representation. Nordic African Institute.

xxi Ellen Johnson Sir-leaf, 'Statement' in Ayodele Aderinwale (ed), Empowering Women for the 21st Empowering Women for the 21st Century. The Challenges of Politics, Business, Development and Leadership. Summary Report of The 9th Annual Conference of the African Leadership Forum in Accra Ghana, 27-29 January, 1997. Ibadan: Intec Printers Ltd. 36

xxii Ayegboyin \& Ishola. 1999. African Indigenous Churches. P. 29 cited in Women in Development...p. 302

xxii Cited in Dehinde, T. 2005. 'Women and Development: A Global Perspective' in ModupeFaseke (ed) Nigerian Women Professionals: A Historic Analysis. Lagos: Tidings Publishers. 1

xxiv Olorunbunmi...p.403

xxv Premium Times. 15-06-2020. Nigeria Records 717 Rape Cases in Five Months. www.allafrica.com Date retrieved 17-06-2020

xxvi Oral interview with Mrs. Oramalu. An indigene of Nibo in Anambra State, Nigeria. Age, 63. 09-03-2020. 